\title{
PENGARUH PEMBIAYAAN PADA PENDAPATAN IJARAH DAN ISTISHNA TERHADAP PROFITABILITAS BANK UMUM SYARIAH DI INDONESIA SELAMA 2015-2018
}

\author{
Surya Indra Yanti \\ Fakultas Agama Islam (FAI), Universitas Islam Riau (UIR) \\ Email : suryaindrayanti@student.uir.ac.id
}

\begin{abstract}
ABSTRAK
Penelitian ini bertujuan untuk mengetahui pengaruh pembiayaan pada pendapatan ijarah dan istishna terhadap profitabilitas bank umum syariah yang terdaftar di BEI. Bank umum syariah yang berjumlah 14 bank umum syariah yang ada di Indonesia pada periode 2015 sampai dengan 2018. Data penelitian ini diperoleh dari data statistik atau laporan keuangan tahunan pada periode 2015-2018 bisa di lihat dari situs resmi www.ojk.go.id. Penelitian ini merupakan penelitian deskriptif dengan menggunakan metode purposive sampling, sampel yang digunakan sebanyak 9 bank umum syariah yang masuk kedalam kriteria dan hipotesis penelitian yang digunakan adalah analisis linier berganda. Dari hasil penelitian ini menunjukkan pendapatan pada pembiayaan ijarah berpengaruh positif terhadap profitabilitas bank umum syariah, sedangkan pada pendapatan pembiayaan istishna berpengaruh negatif terhadap profitabilitas bank umum syariah di Indonesia Pada periode 2015 sampai dengan 2018.
\end{abstract}

Kata kunci: Pembiayaan Ijarah, Pembiayaan Isthisna, Profitabilitas.

\begin{abstract}
This study aims to determine the effect of financing on ijarah and isthisna income on the profitability of Islamic banks listed on the IDX. Islamic commercial banks totaling 14 Islamic commercial banks in Indonesia in the period of 2015 to 2018. The data of this study were obtained from statistical data or annual financial reports in the period 2015-2018, which can be viewed from the official website www.ojk.go.id. This research is a descriptive study using purposive sampling method, the sample used is 9 Islamic commercial banks that are included in the criteria. And the research hypothesis used is multiple linear analysis. From the results of this study show that income on ijarah financing has a positive effect on the provitability of Islamic commercial banks, while Islamic income income has a negative effect on the profitability of Islamic commercial banks in Indonesia in the period 2015 to 2018.
\end{abstract}

Keywords: Ijarah Financing, Isthishna Financing, Profitability. 


\section{PENDAHULUAN}

Bank adalah bagian dari sistem keuangan dan sistem pembayaran disuatu negara, bahkan pada era globalisasi ini. Bank juga menjadi sistem keuangan dan sistem pembayaran dunia. Tujuan bank syariah secara umum untuk mendorong dan mempercepat kemajuan ekonomi masyarakat dengan melakukan kegiatan usahanya. Bank memiliki fungsi yaitu menerima simpanan (funding), meminjamkan uang (landing), dan melayani jasa (service).

Menurut Melina, (2018) pembiayaan dipakai untuk mendefinisikan pendanaan yang dilakukan oleh lembaga pembiayaan seperti BUMN kepada nasabah. Pembiayaan secara luas berarti financing atau pembelanjaan yaitu pendanaan yang dikeluarkan untuk mendukung investasi yang telah direncanakan, baik dilakukan sendiri maupun dikerjakan oleh orang lain.

Perkembangan dan kemajuan bank dapat di lihat dari kemampuan bank dalam melakukan inovasi produk dan jasanya. Bank syariah selalu mengembangkan produk dan jasanya dalam rangka memperoleh keuntungan dan kepuasan bagi nasabah. Salah satu produk dapat dilihat dari pembiayaannya yaitu pembiayaan ijarah dan istishna yang disalurkan kepada nasabah yang memiliki pengaruh terhadap bank syariah. Semakin besar pembiayaan yang disalurkan maka semakin tinggi pula keuntungan yang diperoleh oleh bank syariah, sehingga dapat membantu dalam mengembalikan modal ataupun keuntungan (profit).

Pada penelitian terdahulu, menurut Hustia dan Candera (2019) menyatakan bahwa pembiayaan ijarah dan pembiayaan istishna tidak berpengaruh signifikan terhadap profitabilitas bank umum syariah di Indonesia. Kemudian menurut penelitian Putra (2018) menyatakan bahwa pembiayaan ijarah berpengaruh signifikan terhadap profitabilitas bank umum syariah di Indonesia. Sedangkan menurut penelitian Faradilla, Arfan dan Sabri (2017) menunjukan bahwa pembiayaan ijarah tidak berpengaruh signifikan tterhadap profitabilitas bank umum syariah begitupun pada pembiayaan istishna juga tidak berpengaruh signifikan terhadap profitabilitas bank umum syariah di Indonesia. Dan pada penelitian Nurfajri dan Priyanto (2019) menyatakan bahwa pembiayaan ijarah tidak berpengaruh signifikan terhadap profitabilitas bank umum syariah di Indonesia.

Oleh karena itu, dapat di simpulkan bahwa faktor yang berpengaruh dalam meningkatnya profitabilitas pada bank syariah adalah dari produk-produk pembiayaan yang dimiliki bank syariah tersebut.

\section{TINJAUAN PUSTAKA}

\section{Pembiayaan Ijarah}

Menurut bahasa ijarah adalah sewa, upah atau imbalan. Dalam perbankan syariah ijarah adalah penyedia dana talangan bagi nasabah untuk dapat memperoleh kemanfaatan suatu barang. Menurut fatwa DSN tahun 2000, ijarah adalah akad pemindahan hak guna (manfaat) atas suatu barang (jasa) dalam waktu tertentu dengan membayarkan sewa atau upah tanpa di ikuti dengan pemindahan kepemilikan barang tersebut. Jadi ijarah dapat di definisikan sebagai akad pemindahan hak guna (manfaat) suatu barang atau jasa dalam kurun waktu tertentu dengan pembayaran melalui upah, sewa ataupun imbalan tanpa di ikuti dengan pemindahan atas kepemilikan barang itu sendiri.

\section{Pembiayaan Istishna}

Akad talangan dimana nasabah melakukan pembelian barang, namun pembayaran barang tidak harus dilakukan di awal karena pada akad ini pembayaran bisa dilakukan dengan cara di awal, di cicil, ataupun di lunasi. Barang yang di beli atau di produksi diserahkan kemudian atau belakangan sesuai dengan syarat-syarat yang sudah di sepakati bersama.

\section{Profitabilitas}

Suatu kemampuan atau alat ukur keberhasilan dalam suatu perusahaan dalam menjalankan kegiatan usahanya untuk 
memperoleh keuntungan atau laba dari hasil penjualan barang atau produk jasa yang dihasilkannya. Penelitian Melina dan Zulfa (2020) menyatakan bahwa harga perolehan dan keuntungan yang diterapakan BMT Kota Pekanbaru sesuai dengan kesepakatan bersama antara pengelola dan pembeli. Oleh karena itu BMT tidak menentukan harga perolehan dan keuntugan sendiri melainkan dengan kesepakatan besama, untuk menghindari timbulya riba.

\section{Pengaruh Pembiayaan Ijarah terhadap Profitabilitas}

Pembiayaan ijarah merupakan akad sewa menyewa antara pemilik objek sewa (bank syariah) dan penyewa ( nasabah) untuk mendapatkan imbalan jasa atas objek yang di sewakannya.

Pada penelitian Hustia dan Candera (2019) menyatakan bahwa pembiayaan ijarah dan pembiayaan istishna tidak berpengaruh signifikan terhadap profitabilitas bank umum syariah di Indonesia.

H1 : Di duga pembiayaan pada pendapatan ijarah berpengaruh signifikan positif terhadap profitabilitas bank umum syariah di Indonesia periode 20152018.

Pengaruh Pembiayaan Istishna terhadap Profitabilitas

Pembiayaan istishna merupakan akad jual beli antara pembeli dan produsen yang juga bertindak sebagai penjual. Dengan cara pembayaran dimuka, di cicil, ataupun di tangguhkan sampai jangka waktu tertentu.

Pada penelitian Hustia dan Candera (2019) dan putra (2018) menyatakan bahwa pembiayaan ijarah dan pembiayaan istishna tidak berpengaruh signifikan terhadap profitabilitas bank umum syariah di Indonesia.

$\mathrm{H} 2$ : Diduga pembiayaan pada pendapatan istishna tidak berpengaruh signifikan terhadap profitabilitas bank umum syariah di Indonesia periode 20152018.

\section{METODE PENELITIAN}

\section{Tempat dan waktu penelitian}

Tempat dan waktu penelitian dilakukan pada bank umum syariah yang ada di Indonesia. Bank yang dipilih sesuai dengan kriteria, kemudian data yang di ambil dari hasil laporan keuangan pertahun yang sudah di update dari situs resmi www.ojk.go.id di ambil dari tahun 2015 sampai dengan 2018 dan bank yang juga terdaftar di bursa efek Indonesia (BEI).

\section{Populasi dan Sampel}

Populasi yang digunakan pada penelitian ini sebanyak 14 bank umum syariah yang ada di Indonesia. Kemudian sampel yang digunakan sebanyak 9 bank umum syariah yang sudah di pilih sesuai dengan kriteria dan memiliki data yang lengkap pada laporan keuangan pada tahun 2015 sampai dengan 2018. Adapun 9 bank umum syariah tersebut adalah PT. Bank BCA Syariah, PT. Bank BNI syariah, PT. Bank BRI Syariah, PT. Bank Jabar Banten Syariah, PT.Bank Mega Syariah, PT. Bank Muamalat Indonesia, PT.Maybank Syariah Indonesia, PT. Bank Syariah mandiri, PT. Bank Victoria Syariah.

\section{Jenis Penelitian}

Penelitian ini merupakan data skunder, data yang diperoleh dan dikumpulkan dari perusaan (bank) yang di peroleh dengan cara mengakses situs resmi nya www.ojk.go.id. Data dalam penelitian ini adalah laporan keuangan tahunan yang di pilih menjadi sampel dalam penelitian ini.

\section{Teknik Analisis Data}

Teknik yang digunakan adalah Pengambilan sampel menggunakan
purposive sampling dan teknik analisis menggunakan analisis linier berganda yang di olah menggunakan sofware aplikasi SPPS. Dengan menggunakan metode uji asumsi kalasik, terdiri dari uji normalitas, uji multikolonieritas, uji heteroskedastisitas, uji autokorelasi. Berikutnya uji hipotesis yang terdiri dari uji f, uji t, uji koefesien determinasi (R2). 


\section{HASIL PENELITIAN DAN \\ PEMBAHASAN}

\section{Analisis Deskriptif Variabel Ijarah}

Tabel 1. Analisis Deskriptif Variabel Ijarah

\begin{tabular}{lllllll}
\hline \multirow{2}{*}{ NO } & \multirow{2}{*}{ NAMA BANK } & \multicolumn{5}{c}{$\boldsymbol{I J A R A H}$} \\
\cline { 3 - 6 } & & $\mathbf{2 0 1 5}$ & $\mathbf{2 0 1 6}$ & $\mathbf{2 0 1 7}$ & $\mathbf{2 0 1 8}$ & RATA-RATA \\
\hline 2 & PT. Bank BCA Syariah & 0,00 & 0,00 & 0,00 & 0,00 & 0,00 \\
\hline 3 & PT. Bank BNI syariah & 92,947 & 109,206 & 125,465 & 141,724 & 157,983 \\
\hline 4 & PT. Bank BRI Syariah & 67,608 & 45,837 & 24,066 & 2,295 & $-19,476$ \\
\hline 5 & PT. Bank Jabar Banten Syariah & 12,566 & 11,392 & 10,218 & 9,044 & 7,870 \\
\hline 6 & PT.Bank Mega syariah & 4,542 & 978 & $-2,586$ & -6150 & $-9,714$ \\
\hline 7 & PT. Bank Muamalat Indonesia & 29,721 & 47,651 & 65,581 & 83,511 & 101,441 \\
\hline 8 & PT.Maybank Syariah Indonesia & 33 & 0,00 & 34 & 0,01 & 35 \\
\hline 9 & PT. Bank Syariah mandiri & 188,584 & 216,595 & 244,606 & 272,617 & 300,628 \\
\hline & PT. Bank Victoria Syariah & 259 & 0,00 & 260 & 0,01 & 261 \\
\hline & Maksimum & 49752 & 61953.57 & 58675.13 & 72151.286 & \\
\hline & Minimum & 49532.5 & 71943.17 & 58455.5 & 83840.167 & \\
\hline
\end{tabular}

Sumber : Data Olahan Microsof Excel (2019)

Pada tabel diatas dapat di simpulkan tahun 2015 sampai dengan 2018 selalu bahwa dari 14 bank umum syariah yang ada mengalami penurunan yang cukup signifikan di Indonesia terdapat 9 bank yang di pilih maka akan mempengaruhi profitabilitas pada menjadi sampel yang sesuai dengan kriteria. bank umum syariah di Indonesia. Pada pendapatan pembiayaan ijarah ini dari

\section{Analisis Deskriptif Variabel Istishna}

Tabel 2. Analisis Deskriptif Variabel Istishna

\begin{tabular}{|c|c|c|c|c|c|c|}
\hline \multirow{2}{*}{ NO } & \multirow{2}{*}{ NAMA BANK } & \multicolumn{4}{|c|}{ ISTISHNA } & \multirow[b]{2}{*}{ RATA-RATA } \\
\hline & & 2015 & 2016 & 2017 & 2018 & \\
\hline 1 & PT. Bank BCA Syariah & 0,00 & 0,00 & 0,00 & 0,00 & 0,00 \\
\hline 2 & PT. Bank BNI syariah & 0,00 & 0,00 & 0,00 & 0,00 & 0,00 \\
\hline 3 & PT. Bank BRI Syariah & 3,101 & 1,232 & -637 & $-2,506$ & $-4,375$ \\
\hline 4 & PT. Bank Jabar Banten Syariah & 286 & 221 & 156 & 91 & 26 \\
\hline 5 & PT.Bank Mega syariah & 0,00 & 0,00 & 0,00 & 0,00 & 0,00 \\
\hline 6 & PT. Bank Muamalat Indonesia & 1,991 & 885 & -221 & -1327 & $-2,433$ \\
\hline 7 & PT.Maybank Syariah Indonesia & 10,815 & 9,656 & 8,497 & 7,338 & 6,179 \\
\hline 8 & PT. Bank Syariah mandiri & 1,148 & 83 & -982 & -2047 & $-3,112$ \\
\hline \multirow[t]{4}{*}{9} & PT. Bank Victoria Syariah & 0,00 & 0,00 & 0,00 & 0,00 & 0,00 \\
\hline & Maksimum & 3226 & 2348.83 & 1471.7 & 594.5 & \\
\hline & Minimum & 3468.2 & 2415.4 & 1362.6 & 309.8 & \\
\hline & Rata-rata & 3427.833 & 2404.31 & 1380.8 & 357.25 & \\
\hline
\end{tabular}

Sumber : Hasil Olahan Microsoft Excel (2019) 
Pada tabel di atas dapat disimpulkan bahwa pada pendapatan pembiayaan istishna dari tahun $2015 \mathrm{ke}$ tahun 2016 mengalami kenaikan yang cukup bagus namun pada tahun berikutnya pada tahun 2016 ke 2017 mengalami penurunan Analisis Deskriptif Statistik sampai ke tahun 2018. Karna selalu mengalami penurunan yang cukup signifikan maka akan mempengaruhi profitabilitas yang di hasilkan oleh bank umum syariah periode 2015-2018.

\begin{tabular}{lccc}
\hline \multicolumn{4}{c}{ Tabel 3. Analisis Deskriptif Statistik } \\
\hline Variabel & Mean & Std. Deviation & N \\
\hline Profitabilitas & -45.0572 & 160.98806 & 36 \\
\hline Istishna & 1049.4444 & 3059.50177 & 36 \\
\hline Ijarah & 49961.2242 & 76604.09799 & 36 \\
\hline
\end{tabular}

Sumber : Data Olahan (2019)

Pada tabel diatas dapat disimpulkan bahwa dari 14 bank umum syariah. Terdapat 9 sampel yang menurut kriteria. Pembiayaan ijarah (X1) memiliki pengaruh besar terhadap profitabilitas bank umum syariah. Sedangkan pada pembiayaan istisna kecil pengaruh terhadap profitabilitas bank umum syariah di Indonesia pada periode 2015-2018.

\section{Uji Asumsi Klasik}

\section{Uji Normalitas Data}

Bahwa grafik normal $\mathrm{p}$ plot dapat dilihat dengan menyebarnya titik-titik mendekati garis diagonal sehingga dapat di simpulkan data penelitian terdistribusi secara normal.

\section{Uji Multikolinearitas}

Dapat disimpulkan bahwa model regresi ini tidak mengalami multikolinearitas dan dapat di gunakan dalam penelitian ini.

\section{Uji heteroskedesitas}

Hasil heteroskedesitas menunjukan bahwa data menyebar maka tidak terjadi gejala heteroskedesitas.

\section{Uji Autokorelasi}

Berdasarakan uji Durbin Waston, DU dan DL, dapat disimpulkan tidak terjadi autokorelasi.

\section{Uji Analisis Regresi Linier Berganda}

Tabel 4. Uji Analisi Regresi Linier Berganda

\begin{tabular}{llll}
\hline Variabel & T Hitung & Sig & Keterangan \\
\hline $\mathrm{X} 1$ & 1,307 & 0,200 & Tidak signifikan \\
\hline $\mathrm{X} 2$ & 0,843 & 0,406 & Tidak signifikan \\
\hline & Sumber $:$ Data Olahan $(2019)$ &
\end{tabular}

Sumber : Data Olahan (2019)

$$
\begin{gathered}
\mathrm{Y}=\mathrm{a}+\mathrm{b} 1 \mathrm{X} 1+\mathrm{b} 2 \mathrm{X} 2+\mathrm{e} \\
\mathrm{Y}=-77.335 \mathrm{X} 1+0.00 \mathrm{X} 1-0.11 \mathrm{X} 2+\mathrm{e}
\end{gathered}
$$

Adapun interpretasi dari persamaan regresi tersebut adalah:

ROA $=-77,335$ artinya jika variabel ijarah dan istisna bernilai nol, maka profitabilitas bank umum syariah sebesar $77 \%$.

Mudharabah $=0,00$ artinya apabila bertambah 1 persen maka, profitabilitas bank umum syariah akan meningkat sebesar 0,01 persen dengan asumsi variabel lain bernilai konstan.

Musyarakah = 0,11 artinya apabila bertambah 1 persen maka, profitabilitas bank umum syariah akan menurun sebesar 0,00 persen dengan asumsi variabel lain bernilai konstan. 
Tabel 5. Uji F (Uji Simultan)

\begin{tabular}{lccc}
\hline Variabel & F Hitung & sig & keterangan \\
\hline $\mathrm{X} 1, \mathrm{X} 2$ & 0,983 & 0,385 & Model kurang layak \\
\hline & Sumber : Data & Olahan (2019) \\
Berdasarkan uji simultan bahwa & $\begin{array}{c}\text { menyatakan bahwa pendapatan pembiayaan } \\
\text { nilai f hitung besar dari f tabel dengan nilai f }\end{array}$ & ijarah dan istishna berpengaruh secara \\
hitung sebesar 0,983 dan nilai F tabel sebesar & simultan terhadap variabel Y (profitabilitas) \\
2. Maka model kurang layak. Hipotesis yang & bank umum syariah tidak di terima. \\
Koefisien Determinasi (R2) &
\end{tabular}

Tabel 6. Koefesien Determinasi

\begin{tabular}{llll}
\hline Variabel & RR & Adjusted R square & keterangan \\
\hline $\mathrm{X} 1, \mathrm{X} 2$ & 0,01 & 0,1 & Berpengaruh negatif \\
\hline
\end{tabular}

Sumber : Data Olahan (2019)

Berdasarkan perhitungan yang telah diketahui di atas, nilai R2 sebesar 0,01 yang artinya dimana besarnya dukungan pembiayaan ijarah dan istishna terhadap profitabilitas bank umum syariah sebesar 1\%. Maka variabel ini tidak berpengaruh signifikan terhadap profitabilitas bank umum syariah. Sisanya dipengaruhi oleh variabelvariabel lain yang tidak termasuk dalm penelitian ini.

\section{Uji Hipotesis (Uji T)}

Kesimpulan pada uji $\mathrm{T}$ bahwa pembiayaan ijarah X1 tidak berpengaruh signifikan terhadap profitabilitas bank umum syariah periode 2015-2018 sedangkan pada X2 juga tidak memiliki pengaruh yang signifikan terhadap profitabilitas bank umum syariah periode 2015-2018.

\section{PEMBAHASAN}

\section{Pengaruh Pendapatan Pembiayaan Ijarah terhadap Profitabilitas Bank Umum Syariah.}

Hasil penelitian menunjukkan bahwa pembiayaan ijarah tidak memiliki pengaruh yang signifikan terhadap profitabilitas bank umum syariah. Dimana pada tahun 2017 pembiayaan ijarah yang disalurkan mengalami penurunan yang signifikan dan berdampak berkurangnya profitabilitas yang di dapatkan oleh bank umum syariah. Sebagai mana yang telah kita ketahui ijarah adalah sewa menyewa antara pemilik objek sewa dan si penyewa dengan mendapatkan imbalan jasa atas objek yang disewakannya. Semakin sedikit nasabah yang melakukan akad ijarah pada bank syariah maka semakin kecil pula profit atau keuntungan yang di dapatkan bank syariah. Pendapatan yang diperoleh dari pembiayaan ijarah tersebut mempengaruhi tingkat profitabilitas pada diperoleh. Pernyataan ini di dukung dengan uji t. Hasil penelitian ini sesuai dengan Hustia dan Candera (2019) menyatakan bahwa pembiayaan ijarah dan pembiayaan istishna tidak berpengaruh signifikan terhadap profitabilitas bank umum syariah di Indonesia. Kemudian menurut penelitian Putra (2018) bahwa pembiayaan ijarah berpengaruh signifikan terhadap profitabilitas bank umum syariah di Indonesia. Sedangkan menurut penelitian Faradilla, Arfan dan Sabri (2017) menunjukan bahwa pembiayaan ijarah tidak berpengaruh signifikan terhadap profitabilitas bank umum syariah begitupun pada pembiayaan istishna juga tidak berpengaruh signifikan terhadap profitabilitas bank umum syariah di Indonesia. Dan pada penelitian Nurfajri (2019) menyatakan bahwa pembiayaan ijarah tidak berpengaruh signifikan terhadap profitabilitas bank umum syariah di Indonesia. 
Pengaruh Pembiayaan Istishna pada Profitabilitas Bank Umum Syariah.

Hasil penelitian ini menunjukan bahwa pembiayaan istishna tidak berpengaruh signifikan terhadap profitabilitas bank umum syariah karena pendapatan istishna pada setiap tahunnya mengalami penurunan yang sangat signifikan sehingga berpengaruh terhadap profitabilitas yang di hasilkan oleh bank umum syariah. Pernyataan ini didukung dengan uji $\mathrm{t}$ hasil penelitian ini sesuai dengan penelitian yang dilakukan oleh Hustia dan Candera (2019) menyatakan bahwa pembiayaan ijarah dan pembiayaan istishna tidak berpengaruh signifikan terhadap profitabilitas bank umum syariah di Indonesia. Kemudian menurut penelitian purnama putra (2018) bahwa pembiayaan ijarah berpengaruh signifikan terhadap profitabilitas bank umum syariah di Indonesia. Sedangkan menurut penelitian Faradilla, Arfan dan Sabri (2017) menunjukan bahwa pembiayaan ijarah tidak berpengaruh signifikan terhadap profitabilitas bank umum syariah begitupun pada pembiayaan istihna juga tidak berpengaruh signifikan terhadap profitabilitas bank umum syariah di Indonesia. Dan pada penelitian Nurfajri (2019) menyatakan bahwa pembiayaan ijarah tidak berpengaruh signifikan terhadap profitabilitas bank umum syariah di Indonesia.

\section{PENUTUP}

Berdasarkan hasil dari penelitian di atas dapat di simpulkan bahwa :

1. Pembiayaan pada pendapatan ijarah tidak berpengaruh positif terhadap profitabilitas bank umum syariah di Indonesia periode 2015-2018.

2. Pembiayaan pada pendapatan istishna juga tidak berpengaruh positif terhadap profitabilitas bank umum syariah di Indonesia periode 2015-2018.
3. Secara simultan, pembiayaan pada pendapatan ijarah dan Pendapatan istishna tidak berpengaruh positif terhadap profitabilitas bank umum syariah di Indonesia periode 2015-2018.

\section{DAFTAR PUSTAKA}

Faradilla, Cut., Arfan, Muhammad, \& Shabri, M. 2017. Pengaruh Pembiayaan Murabahah, Istishna, Ijarah, Mudharabah Dan Musyarakah Terhadap Profitabilitas Bank Umum Syariah Di Indonesia. Jurnal Magister Akuntansi Pascasarjana Universitas Syiah Kuala, Vol. 6, No. 3.

Hustia, Anggreany \& Candera, Mister. 2019. Pengaruh Pembiayaan Qardh, Ijarah dan Istishna Terhadap Profitabilitas Bank Pembiayaan Rakyat Syariah (BPRS) Di Indonesia. Jurnal Manajemen dan Keuangan, Vol. 8, No.1.

Melina, F., \& Zulfa, M. 2020. Implementasi Pembiayaan Murabahah pada Baitul Mal Wat Tamwil (BMT) Kota Pekanbaru. COSTING: Journal of Economic, Business and Accounting, 3(2), 356-364.

Melina, F. 2018. Pembiayaan Pinjaman Lunak Usaha Kecil Ikan Patin dengan PT. Telkom Pekanbaru Melalui Mitra Binaan Menurut Ekonomi Islam. Syarikat: Jurnal Rumpun Ekonomi Syariah, 1(1), 53-62.

Nurfajri, Fajri., \& Priyanto, Toni. 2019. Pengaruh Murabahah, Musyarakah, Mudharabah, Dan Ijarah Terhadap Profitabilitas Bank Umum Syariah Di Indonesia. Jurnal Monex, Vol. 8, No. 2.

Putra, Purnama. 2018. Pengaruh Pembiayaan Mudharabah, Musyarakah, Murabahah, Dan Ijarah Terhadap Profitabilitas Bank Umum Syariah Periode 20132016. Jurnal Organisasi dan Manajemen, Vol. 14, No. 2. 